\title{
Floating layer formation, foaming, and microbial community structure change in full-scale biogas plant due to disruption of mixing and substrate overloading
}

Tobias Lienen', Anne Kleyböcker, Manuel Brehmer², Matthias Kraume², Lucie Moeller ${ }^{3}$ Kati Görsch³ and Hilke Würdemann ${ }^{1 *}$

\begin{abstract}
Background: The use of biogas as renewable resource of energy is of growing interest. To increase the efficiency and sustainability of anaerobic biogas reactors, process failures such as overacidification, foaming, and floating layers need to be investigated to develop sufficient countermeasures and early warning systems to prevent failure.

Methods: Chemical, rheological, and molecular biological analyses were conducted to investigate a stirring disruption in a full-scale biogas plant.

Results: After the agitation system was disturbed, foaming and floating layer formation appeared in a full-scale biogas plant fed with liquid manure and biogenic waste. Rheological characterizations and computational fluid dynamics (CFD) revealed a breakdown of the circulation within the reactor and a large stagnation zone in the upper reactor volume. Molecular biological analyses of the microbial community composition in the floating layer showed no differences to the digestate. However, the microbial community in the digestates changed significantly due to the stirring disturbances. Foam formation turned out to be a consequence of overloading due to excessive substrate supply and disturbed mixing. The subsequent increase in concentration of both acetic and propionic acids was accompanied by foaming.
\end{abstract}

Conclusions: Effective mixing in full-scale biogas plants is crucial to avoid foaming and floating layers and to enhance sustainability. Disturbed mixing leads to process imbalances and significant changes in the microbial community structure. Additionally, controlled feeding might help prevent foam formation due to overloading.

Keywords: Full-scale biogas plant; Biogenic waste; Floating layer; Agitator disruption; DGGE; Foam formation

\section{Background}

Anaerobic cofermentation of biogenic wastes to produce biogas is of growing interest to generate renewable energy and to reduce greenhouse gas emissions. The production of biogas by biogenic wastes is a decentralized technology and contributes toward the renewable energy turnaround in Germany. Biogas plants are often affected by process failures such as overacidification or foam and floating layers that reduce the efficiency of plants. A

\footnotetext{
* Correspondence: wuerdemann@gfz-potsdam.de

'GFZ German Research Centre, Telegrafenberg, 14473 Potsdam, Microbial

GeoEngineering, Germany

Full list of author information is available at the end of the article
}

breakdown of the biogas production process because of process failures leads to enormous economical loss and deteriorated sustainability [1]. Selection of suitable substrates and proper mixing are important challenges in the biogas production industry to avoid failures of the process. Feeding with profitable but unsuitable substrates may lead to serious process interruptions. An overacidification event is often caused by substrate overloading and accumulation of volatile fatty acids (VFA) [2]. Kleyböcker et al. [3] developed two early warning indicators in terms of overacidification. The first indicator (EWI-VFA/Ca) is characterized 
by the relation of VFA to $\mathrm{Ca}^{2+}$ and was shown to provide a warning 5 to 7 days before an overacidification appeared. The warning is indicated by a two- to threefold increase of values. The second early warning indicator (EWI$\mathrm{PO}_{4} / \mathrm{Ca}$ ) is characterized by the relation of $\mathrm{PO}_{4}^{3-}$ to $\mathrm{Ca}^{2+}$. Moeller et al. [4] showed a correlation between the fed substrates as well as inadequate plant management and the formation of foam in biogas plants. Foaming can be caused by high concentrations of VFA, surface-active compounds, detergents, proteins, and high nitrogen concentrations as well as organic overloading [4]. In contrast, the formation of floating layers is mainly triggered by inadequate mixing and feeding of fibrous substrates [5]. Besides the chemical and physical characteristics of the substrates and the plant management, foam and floating layers are also promoted by growth of filamentous bacteria $[6,7]$. Most of the studies regarding the filamentous bacteria were done in activated sludge treatment plants and anaerobic digesters fed by sewage sludge. In these systems, mainly Gordonia spp. and Microthrixparvicella were identified as foam causers $[8,9]$. Using their filamentous structure, the microorganisms trap biogas bubbles, which transfer them to the surface. The hydrophobic cell surface promotes and stabilizes the foam as well as the release of hydrophobic substances. Foaming and the formation of floating layers may cause serious damage in biogas plants [10]. The active volume of the digester is reduced leading to an inefficient gas recovery. Furthermore, gas mixing devices may be blocked, gas pipelines may be fouled, and even the roof may be damaged by the pressure of the foam or floating layer. In addition, the economical costs of energy loss, manpower overtime, and cleaning costs have to be taken into consideration [11]. Although several studies on foam formation in anaerobic digesters treating activated sludge were published [8,12], formation of floating layers and foam in anaerobic digesters fed with biogenic waste and the impact of mixing procedures in full-scale biogas plants as well are still rarely investigated. Most importantly, information about the chemical composition and microbial community structure of the floating layer is lacking due to the difficulties of sample collection in fullscale digesters. The objective of the study presented in this paper was to investigate the alterations in rheological, chemical, and microbiological parameters during an agitator disruption accompanying floating layer and foam formation in a full-scale biogas plant treating biogenic waste. In addition, the repair of a broken stirring paddle allowed for analyzing a floating layer chemically and microbiologically. Furthermore, two early warning indicators for overacidifications were used to investigate the process performance in the floating layer. The results of this study give further insight into the improvement of the efficiency of the biogas production process as well as understanding of the complex microbial community composition.

\section{Methods}

Biogas plant scheme, process operation, and sampling

The full-scale biogas plant was run as a two-stage plant consisting of two hydrolysis reactors $\mathrm{H} 1$ and $\mathrm{H} 2\left(520 \mathrm{~m}^{3}\right)$ operated at $30^{\circ} \mathrm{C}$ and two methanogenic reactors $\mathrm{R} 1$ and $\mathrm{R} 2\left(2,300 \mathrm{~m}^{3}\right)$ operated at $37^{\circ} \mathrm{C}$ (Figure 1$)$. The hydraulic retention time was kept within the range of 26 days. Liquid manure (50,000 t/a) and a highly variable combination of biogenic wastes $(30,000 \mathrm{t} / \mathrm{a})$ from the fish industry and oil from fat separators as well as creamery and slaughterhouse waste were fed as substrates. R1 and R2 were charged in turn every $4 \mathrm{~h}$ by $15 \mathrm{~m}^{3}$ substrate. Mixing was conducted by continuous stirring with paddles in two different heights. The methanogenic reactors were operated at an organic loading rate between 2 and $2.5 \mathrm{~kg} \mathrm{VS} \mathrm{m}^{-3}$ day $^{-1}$. The produced biogas consisted of $60 \%$ to $65 \% \mathrm{CH}_{4}$. The biogas production was about 4.4 million $\mathrm{m}^{3} / \mathrm{a}$ while the digestate residues yielded $61,000 \mathrm{t} / \mathrm{a}$. The methanogenic reactors $\mathrm{R} 1$ and $\mathrm{R} 2$ were monitored from the start of an agitator breakdown in these reactors over a period of 6 months. In month 5, stirring was reconstituted. While

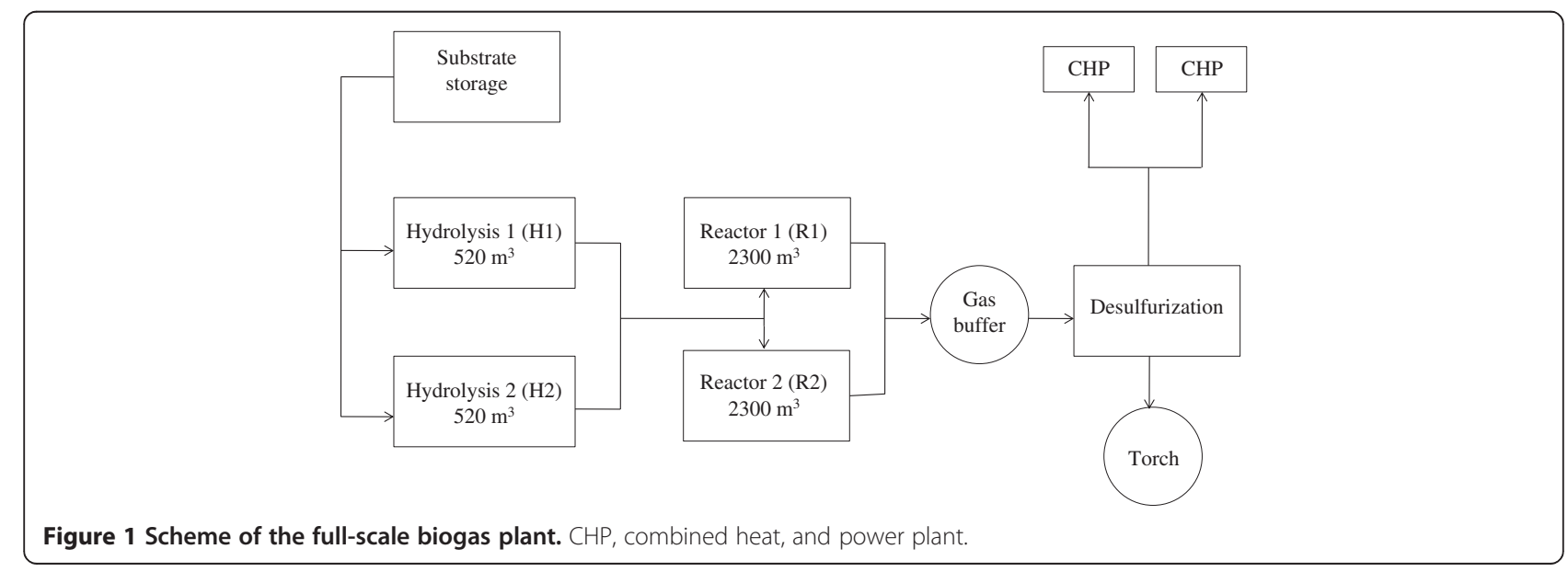


the agitator motor in R1 broke down completely, R2 was affected by one broken stirring paddle (Figure 2a). During the first month, foam was observed in both reactors. The foam disappeared after 1 day without intervention. Additionally, a sample of a floating layer was directly collected during the reparation process of the broken paddle in R2 in month 5 (Figure 2b). In the first month, digester samples were withdrawn at the drain at the bottom of the two reactors biweekly. Afterward, sampling was conducted monthly.

\section{Chemical analyses}

For the total solids (TS) and the volatile solids (VS), about $50 \mathrm{~g}$ of the samples was dried at $105^{\circ} \mathrm{C}$ in a Memmert drying chamber (Memmert $\mathrm{GmbH}$, Hannover, Germany) for $24 \mathrm{~h}$ and then burned at $550^{\circ} \mathrm{C}$ (Nabertherm Controller B170; Nabertherm GmbH, Lilienthal/Bremen, Germany). The weight of the samples was determined using a Sartorius CP220S-OCE balance (Sartorius AG, Goettingen, Germany) (scale $\pm 0.01 \mathrm{~g}$ ). The TS and VS were analyzed according to German guideline DIN 38409-1 [13]. For the chemical parameters and for DNA extraction, the samples were centrifuged $10 \mathrm{~min}$ at $12,857 \times g$ to pelletize solid substances. Pellets were transferred into $1.5 \mathrm{~mL}$ tubes and stored at $-20^{\circ} \mathrm{C}$ to extract DNA afterward. The supernatant was centrifuged again for $10 \mathrm{~min}$ at $12,857 \times \mathrm{g}$. The volatile fatty acids (VFA), calcium $\left(\mathrm{Ca}^{2+}\right)$, and phosphate $\left(\mathrm{PO}_{4}^{3-}\right)$ concentrations were measured photometrically (Hach-Lange DR2800, Hach-Lange cuvette tests LCK 365, 327, and 350; Hach Lange GmbH, Düsseldorf, Germany) in the second supernatant. Additionally, the two early warning indicators EWI-VFA/Ca and EWI$\mathrm{PO}_{4} / \mathrm{Ca}$ for overacidifications and process imbalances [3] were tested. The nitrogen and organic/inorganic carbon concentrations were detected in homogenized (using a common hand-held blender) samples by a TOC$\mathrm{VCSH} / \mathrm{CSN}$ analyzer containing a TN-unit (Shimadzu, Nakagyo-ku, Kyoto, Japan). The crude protein concentration was determined according to the method of Dumas [14] with a modified determination method of total nitrogen concentration (videsupra). The factor volatile organic acids/total inorganic carbonate buffer (VOA/TIC) determines the buffer capacity of the biogas producing system [15]. The VOA/TIC analysis was carried out according to the Nordmann method [16] using $20 \mathrm{~mL}$ of centrifugation supernatant $\left(20 \mathrm{~min}, 5,300 \mathrm{rpm}\right.$, and $20^{\circ} \mathrm{C}$; Beckman Avanti 30 centrifuge, Brea, CA, USA). The 10-mL samples were filtered through a membrane filter (nylon, $0.45 \mu \mathrm{m}$, Pall Corp, Port Washington, NY, USA) for further analysis. The ammonia nitrogen concentration was measured using the spectrophotometric test kit Spektroquant $^{\oplus}$ (Merck KGaA, Darmstadt, German) with photometer MuliLab P5 (WTW, Weilheim, Germany). The concentrations of volatile organic acids (acetic acid, propionic acid, and butyric acid) were measured by use of HPLC (Shimadzu: VA 300/7.8 nucleogelion 300 OA column, $0.01 \mathrm{~N} \mathrm{H}_{2} \mathrm{SO}_{4}$ as eluent, and the detector RID-10A). Water-elutable elements were determined by ICP-AES (according to EN ISO 11885, Spectro, Kleve, Germany).

\section{Rheological characterization}

Due to the complex structure of the substrate, the viscosity was determined by using different measuring systems. Three relative methods - a pipe viscosimeter, a paddle mixer, and a ball measuring system - were compared with two standardized methods: the double gap and the cylinder measuring system. In the double gap measuring system, an additional static cylinder is in the center and the rotating measuring cylinder is hollow. Thus, two spaces are created between the inner stator and rotor as well as between the rotor and the outer wall. The calculations of the apparent viscosity $\eta_{S}$ and the shear rate $\dot{\gamma}$ are summarized in Table 1 . The measurement systems used to describe the rheology differ in their measuring range. Apart from the results of the double gap measuring system, the viscosity showed the expected dependence on the shear rate. The higher values of this measuring system were due to the large friction of the particles contained in the substrate at the

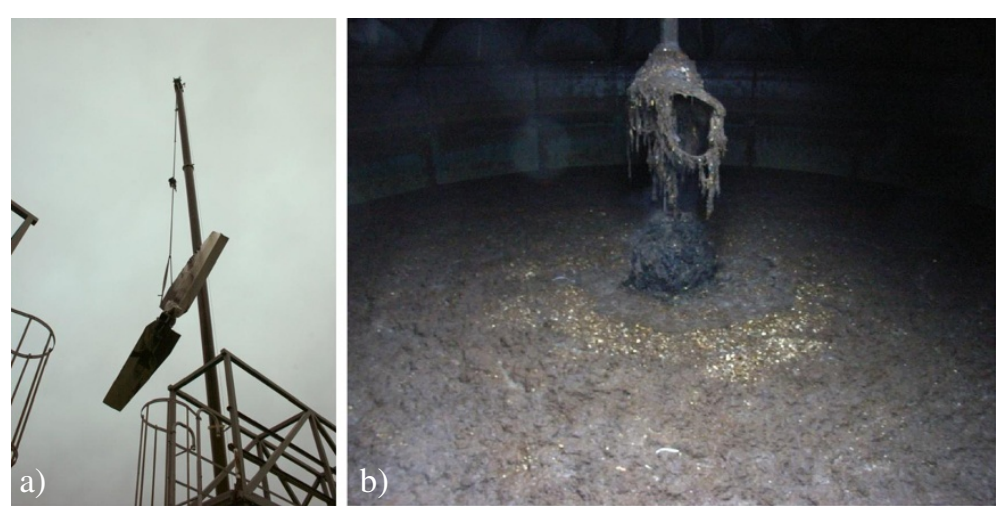

Figure 2 Broken stirring paddle and floating layer in R2. (a) Exchange of broken stirring paddle in R2. (b) Floating layer in R2. 
Table 1 The calculation of the apparent viscosity $\eta_{s}$ and the shear rate $\dot{Y}[17,18]$

\begin{tabular}{|c|c|c|}
\hline Measuring system & Equation & Constant \\
\hline \multirow[t]{5}{*}{ Double gab measuring system } & \multirow{3}{*}{$\tau=\frac{1+\delta^{2}}{\left(\delta^{2} \cdot R_{3}^{2}+R_{2}^{2}\right)} \cdot \frac{M}{4000 \cdot \cdot \pi L C_{L}}$} & $C_{L}=1.10$ \\
\hline & & $\delta=1.0245$ \\
\hline & & $R_{\mathrm{MKi}}=20.25 \mathrm{~mm}$ \\
\hline & \multirow{2}{*}{$\dot{\gamma}=\omega \cdot \frac{1+\delta^{2}}{\delta^{2}-1}$} & $R_{\mathrm{MKa}}=21.00 \mathrm{~mm}$ \\
\hline & & $L=78.7 \mathrm{~mm}$ \\
\hline \multirow[t]{4}{*}{ Cylinder measuring system } & \multirow[t]{2}{*}{$\tau=\frac{1+\delta^{2}}{2000 \cdot \delta^{2}} \cdot \frac{M}{2 \pi L \cdot R_{i}^{2} \cdot C_{L}}$} & $C_{L}=1.10$ \\
\hline & & $\delta=1.0848$ \\
\hline & \multirow{2}{*}{$\dot{\gamma}=\omega \cdot \frac{1+\delta^{2}}{\delta^{2}-1}$} & $R_{\mathrm{MKi}}=13.33$ \\
\hline & & $L=40.003 \mathrm{~mm}$ \\
\hline \multirow[t]{3}{*}{ Ball measuring cell } & $\tau=C_{s s} \cdot M$ & $C_{S S}=15.0 \frac{\mathrm{Pa}}{\mathrm{mNm}}$ \\
\hline & \multirow[t]{2}{*}{$\dot{\gamma}=C_{S R} \cdot n$} & $C_{S R}=0.427 \frac{\mathrm{min}}{\mathrm{s}}$ \\
\hline & & $d_{K}=12.0 \mathrm{~mm}$ \\
\hline \multirow[t]{5}{*}{ Paddle mixer [17] } & \multirow{2}{*}{$N e=\frac{p}{p \cdot n^{3} \cdot d^{5}}=\frac{C_{\text {lam }}}{R e} C_{\text {turb }}$} & $C_{\mathrm{MO}}=10.94$ \\
\hline & & $C_{\text {lam }}=189.6$ \\
\hline & \multirow[t]{3}{*}{$\dot{\gamma}=C_{\mathrm{MO}} \cdot n$} & $C_{\text {turb }}=9.4$ \\
\hline & & $d_{R}=30 \mathrm{~mm}$ \\
\hline & & $d_{B}=143 \mathrm{~mm}$ \\
\hline \multirow[t]{3}{*}{ Pipe viscosimeter [18] } & \multirow{3}{*}{$\begin{array}{l}T_{w}=\frac{d \cdot \Delta p}{4 \cdot L} \\
\left(\frac{d w}{d r}\right)_{w}=\frac{3 n^{\prime}+1}{4 n^{\prime}} \cdot \frac{8 \cdot w_{m}}{d} \\
n^{\prime}=\frac{d n\left(\frac{d \cdot \Delta p}{4 \cdot L}\right)}{d n \frac{\left(8 \cdot w_{m}\right)}{d}}\end{array}$} & $L_{\text {pipe }}=2,500 \mathrm{~mm}$ \\
\hline & & $d_{\text {pipe }}=43.2$ \\
\hline & & \\
\hline
\end{tabular}

stator because of the small gap width. Based on this comparative study, the cylinder measuring system was chosen for further viscosity monitoring because it was easy to handle and required a comparably low sample volume. The rheological characterization of the substrates was performed over a period of more than 1 year, including the period when the agitator system was disrupted. The shear thinning characteristics of the substrate are described by the power law equation $\eta_{S}=K \cdot \dot{\gamma}^{n-1}$, wherein $K$ stands for the Ostwald factor and $\eta$ for the shear rate exponent. Based on this equation, the flow regime of the biogas plant with its typical rheological characteristic was determined using the computational fluid dynamics (CFD) software CCM+. The cylindrical model, with a diameter of $13 \mathrm{~m}$ and a height of $15.3 \mathrm{~m}$, had a two-stage central mixer in line with the plant. The height was equal to the liquid level; therefore, the ceiling of the cylinder and the boundary layer between the liquid and the gas phase was modeled assuming slip conditions. The lower agitator had a diameter of $4.2 \mathrm{~m}$ and was installed $4 \mathrm{~m}$ above the ground. A second agitator with a diameter of $2 \mathrm{~m}$ was placed at a height of $12 \mathrm{~m}$ above the ground. Both impellers were attached to the same shaft. The resulting liquid volume was displayed in the CFD software with a polyhedron grid and approximately 4 million cells. This calculation area was broken down into a stagnant self-contained cylinder and a rotating cylinder. To model the transfer of mass, momentum, energy, and other physical quantities between these two regions, the 'indirect' interface was used. For consideration of the agitator moving, the socalled moving reference frame model was applied. The rotation frequency was $42 \mathrm{rpm}$ and steady state conditions were assumed. To compare both relevant process conditions, with and without a disrupted agitator, a second simulation with disrupted stirring was performed, while the boundary conditions were kept constant and the lower agitator blades were removed.

\section{DNA extraction and PCR-DGGE analysis}

To compare the diversity in the microbial community compositions, the total genomic DNA was extracted from $350 \mathrm{mg}$ of the pellets using the MP Fast DNA Spin Kit for Soil according to the manufacturer's instructions. The partial 16S rRNA genes (566 bp) of the bacterial community were amplified by polymerase chain reaction (PCR) in $50 \mu \mathrm{L}$ reactions with $1 \mu \mathrm{L}$ of $1: 10$ diluted template using the primer pair $341 \mathrm{~F}-\mathrm{GC} / 907 \mathrm{R}[19,20]\left(94^{\circ} \mathrm{C}\right.$ 2:45 min, $94^{\circ} \mathrm{C} \mathrm{0:45} \mathrm{min,} 56^{\circ} \mathrm{C} \mathrm{0:45} \mathrm{min,} 72^{\circ} \mathrm{C} \mathrm{0:50} \mathrm{min,}$ $72^{\circ} \mathrm{C} 30 \mathrm{~min}, 40$ cycles). Amount of $50 \mu \mathrm{L}$ of reactions was mixed containing $5 \mu \mathrm{L} 10 \times$ reaction buffer (Genecraft, Lüdinghausen, Germany), $6 \mu \mathrm{L}$ dNTPs $(10 \mathrm{mM}$, Fermentas, Thermo Fisher Scientific, Waltham, MA, USA), $3 \mu \mathrm{L} \mathrm{MgCl}_{2}$ (50 mM, Genecraft), $3 \mu \mathrm{L}$ forward primer $(10 \mathrm{mM}), 3 \mu \mathrm{L}$ reverse primer $(10 \mathrm{mM}), 0.4 \mu \mathrm{L}$ BSA $(20 \mathrm{mg} / \mathrm{mL}$, Fermentas), $0.3 \mu \mathrm{L}$ Taq polymerase $(5 \mathrm{u} / \mu \mathrm{L}$, Genecraft), $28.3 \mu \mathrm{L}$ RNA/DNA-free water (Fermentas), and $1 \mu \mathrm{L}$ of 1:10 diluted template. Amplicons were purified subsequently using the Fermentas GeneJET PCR Purification Kit (Fermentas, Thermo Fisher Scientific, Waltham, MA, USA) and the amplicon concentration was determined fluorimetrically (BMG Labtech FLUOstar OPTIMA; BMG LABTECH GmbH, Allmendgruen, Ortenberg, Germany) by labeling the DNA with QuantiTPicoGreen (Invitrogen, Darmstadt, Germany). Denaturing gradient gel electrophoresis (DGGE) was performed afterward with equal concentrations of amplicons and a gradient of $35 \%$ to $65 \%$ urea and 6\% acrylamide (BioradDCode System, Munich, Germany). The DGGE gel ran for $17 \mathrm{~h}$ at $110 \mathrm{~V}$ and $60^{\circ} \mathrm{C}$. Bands of interest were excised and transferred into a $0.5-\mathrm{mL}$ tube. Amount of $50 \mu \mathrm{L}$ of sterile $\mathrm{H}_{2} \mathrm{O}$ was added and removed directly to wash the gel pieces. Afterward, $30 \mu \mathrm{L}$ sterile $\mathrm{H}_{2} \mathrm{O}$ was added. The tube was shaken for $1 \mathrm{~h}$ at $37^{\circ} \mathrm{C}$ to recover the DNA out of the gel. Reamplification was carried out using $4 \mu \mathrm{L}$ template of recovered DNA and the primer pair $341 \mathrm{~F} / 907 \mathrm{R}\left(94^{\circ} \mathrm{C} 1: 30 \mathrm{~min}, 94^{\circ} \mathrm{C} 0: 30 \mathrm{~min}, 56^{\circ} \mathrm{C}\right.$ 0:30 min, $72^{\circ} \mathrm{C} 0: 30 \mathrm{~min}, 72^{\circ} \mathrm{C} 10 \mathrm{~min}, 30$ cycles). PCR products were purified using the Avegene gel/PCR 
DNA fragments extraction kit (MSP KOFEL, Zollikofen, Switzerland), and the DNA concentrations were measured fluorimetrically according to the procedure mentioned above. The PCR products were sent in and sequenced by GATC Biotech AG (Jakob-Stadler-Platz 7, Konstanz, Germany). Sequences were edited using the BioEdit Sequence Alignment Editor version 7.0.5.3 [21]. Basic Local Alignment Search Tool (BLAST) [22] was used for sequence similarity check, and the taxonomic assignment was done by Ribosomal Database Project (RDP) using the RDP Classifier [23]. Based on the DGGE profiles, a graphical representation of the bacterial community evenness was set by using Pareto-Lorenz (PL) distribution curves [24] as previously described by Wittebolle et al. [25]. GelQuant.NET software provided by biochemlabsolutions.com was used to determine the band intensities. The band intensities for every DGGE lane were ranked from high to low and the cumulative band intensities were used as the $y$-axis. The cumulative normalized number of bands was set as the $x$-axis. Evaluation of the curves was conducted by comparison to a vertical $20 \% x$-axis line. The theoretical perfect evenness line was set as $45^{\circ}$ diagonal.

\section{Microscopy}

The floating layer sample was analyzed by bright field microscopy at a $\times 100$ magnification (Zeiss Axio Imager M2; Carl Zeiss, Oberaue 3, Jena, Germany). Therefore, the sample was added to a drop of water on an object slide and viewed microscopically afterward.

\section{Results and discussion}

\section{Foam formation related to substrate overloading}

Formation of foam was observed in both methanogenic reactors on day 12 in the first month after high organic loading and agitator break-down. Since the monitoring started when the stirring was disturbed, chemical analyses for the period before were not accessible. Besides breakdown and disturbance of stirring as a cause for the foam formation during the first month in both methanogenic reactors, changes in the substrate mix also have to be considered (Figure 3). The hydraulic retention time of the hydrolytic reactors was 11.2 days, and considering that the substrate feeding occurred in the period of 12 days before foaming in the methanogenic reactors, a peak in the total quantity of fed substrates was applied by the operator. After breakdown of agitation foaming occurred. The chemical characterization of the digestate from the time period before and after foaming is shown in Table 2 . The increase of VOA/TIC values amounted to 0.08 and 0.06 during 4 days in both methanogenic reactors, respectively. Accordingly, the concentrations of VOA rose from $1,600 \mathrm{mg} \mathrm{L}^{-1}$ (R1) and $1,650 \mathrm{mg} \mathrm{L}^{-1}$ (R2) to $2,700 \mathrm{mg} \mathrm{L}^{-1}(\mathrm{R} 1)$ and $2,500 \mathrm{mg} \mathrm{L}^{-1}(\mathrm{R} 2)$, respectively.
The concentration of acetate increased in R1 from less than $1 \mathrm{mg} \mathrm{L}^{-1}$ to $400 \mathrm{mg} \mathrm{L}^{-1}$ and in $\mathrm{R} 2$ from $100 \mathrm{mg} \mathrm{L}^{-1}$ to $200 \mathrm{mg} \mathrm{L}^{-1}$. Moreover, in only one sample, $66 \mathrm{mg} \mathrm{L}^{-1}$ of propionic acid was detected in R2 1 day after the foaming occurred. The acetic acid concentration decreased in R1 5 days after foaming, while it was 2.5 -fold increased in R2. Presumably, high feeding together with disturbed mixing led to an overloading of the reactors. Some of the fed substrates such as fish and slaughterhouse waste as well as easily degradable substrates such as sugar beet molasses are well known to favor foaming [26,27]. Although the VOA/TIC is specific for each biogas plant, a sudden change in the VOA/TIC curve indicates a process disturbance. The accumulation of intermediates of the biogas producing process is known to be a consequence of failure of the microbial process that can be due to organic overloading [28]. One and two days before foaming appeared, the early warning indicators EWI-VFA/Ca and $\mathrm{EWI}-\mathrm{PO}_{4} / \mathrm{Ca}$ increased by a factor of 2 (Figure 4). According to Kleyböcker et al. [3], the increase indicates a warning in terms of overacidification and overloading. Because the overloading is regarded as a reason for foaming, the EWI$\mathrm{VFA} / \mathrm{Ca}$ and $\mathrm{EWI}-\mathrm{PO}_{4} / \mathrm{Ca}$ warned in terms of foam formation as well. The ammonia nitrogen concentration was more or less constant. One day after foaming, the crude protein concentration increased considerably in R1, while it stayed almost stable in R2. Furthermore, the protein concentration decreased considerably in both methanogenic reactors 5 days after foaming. Concerning water eluable elements, diverse trends were observed. Calcium and magnesium concentrations were higher in both fermenters 1 day after foaming than in the period before foaming. The calcium concentration decreased again in both methanogenic reactors 5 days after foaming. The magnesium concentration had an opposite tendency in both fermenters; it rose further in R1 while sinking in R2. Nickel was detected with a concentration of about $20 \mathrm{mg} \mathrm{L}^{-1}$ in both methanogenic reactors 1 day after foaming. All other element concentrations were either stable or only slightly higher in the period after foaming (Table 2). The role of water eluable elements in the foam formation in biogas plants has not been studied so far. Nevertheless, the experience from fermentation processes in digestive systems of ruminants may help to understand biogas systems. Miltimore [29] found that calcium, nickel, and zinc were associated with the bloat of ruminants, whereas magnesium had no relation to foaming in the rumen. The increased calcium and nickel concentrations during the foam formation most likely resulted from the variances in the substrate mix. Moreover, there was a considerable drop in the biogas production rate after the foaming (Figure 3), also indicating a process imbalance. Unfortunately, no sampling of the foam from the reactor surface was possible to analyze 


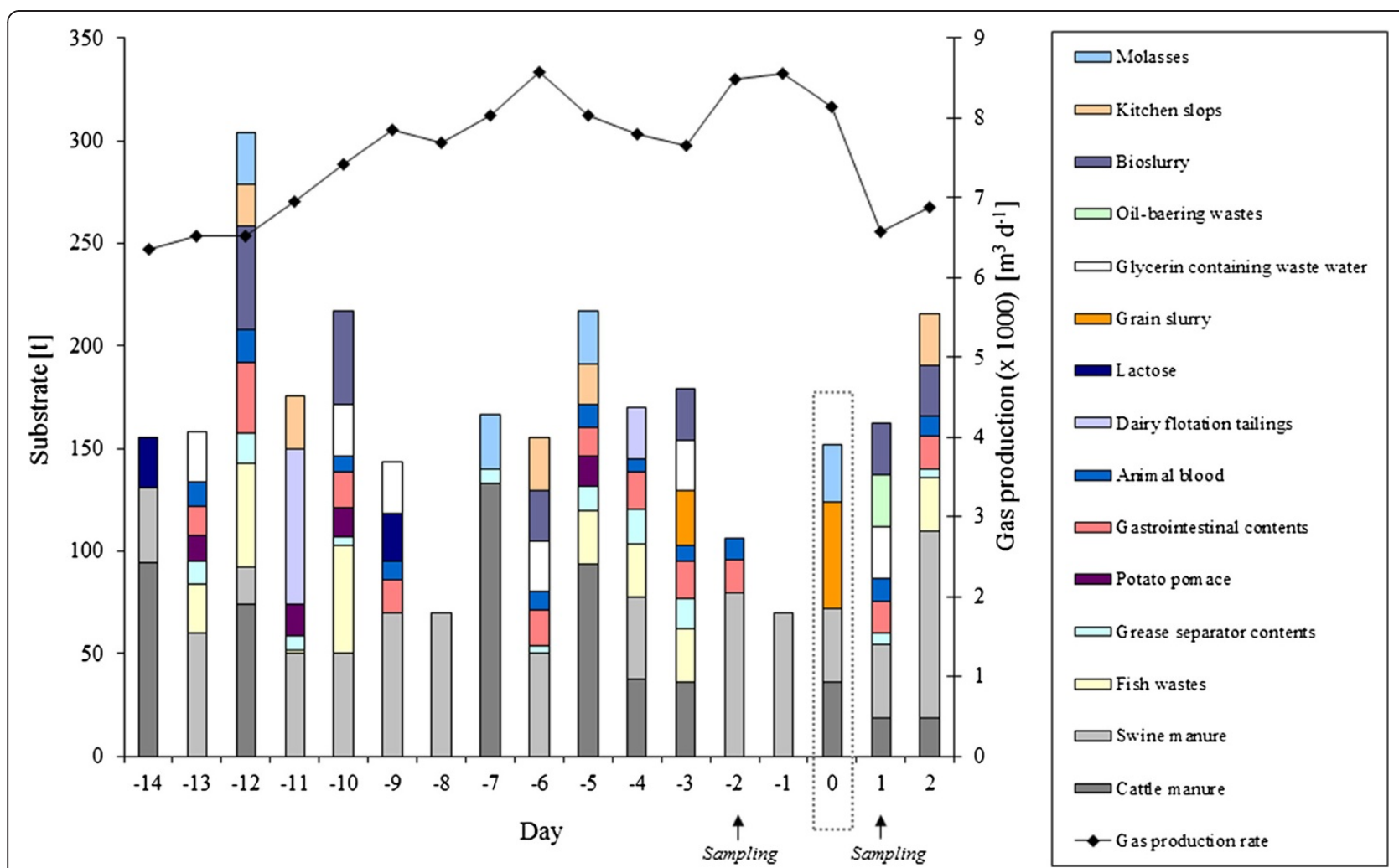

Figure 3 Substrate feeding ratios during and before the foaming period in month $\mathbf{1}$. The dashed lined rectangle indicates the day when both methanogenic reactors foamed (day ' 0 '). High substrate loading was detected 12 days before the foam appeared.

Table 2 Chemical characterization of the digestate of the methanogenic reactors R1 and R2 during foaming

\begin{tabular}{|c|c|c|c|c|c|c|}
\hline & \multicolumn{2}{|c|}{ Two days before foaming } & \multicolumn{2}{|c|}{ One day after foaming } & \multicolumn{2}{|c|}{ Five days after foaming } \\
\hline & R1 & R2 & R1 & R2 & R1 & R2 \\
\hline VOA/TIC (-) & $0.093 \pm 0.006$ & $0.098 \pm 0.008$ & $0.170 \pm 0.023$ & $0.155 \pm 0.002$ & $0.134 \pm 0.036$ & $0.0173 \pm 0.038$ \\
\hline Total carbon $\left(\mathrm{g} \mathrm{L}^{-1}\right)$ & $16.42 \pm 0.86$ & $15.55 \pm 0.69$ & $18.63 \pm 1.23$ & $13.67 \pm 0.30$ & $15.87 \pm 0.58$ & $15.80 \pm 0.66$ \\
\hline Total organic carbon $\left(\mathrm{g} \mathrm{L}^{-1}\right)$ & $12.23 \pm 0.76$ & $11.44 \pm 0.64$ & $14.04 \pm 0.52$ & $9.793 \pm 250$ & $11.87 \pm 0.51$ & $11.75 \pm 0.66$ \\
\hline Total nitrogen $\left(\mathrm{g} \mathrm{L}^{-1}\right)$ & $4.63 \pm 0.24$ & $4.57 \pm 0.19$ & $5.14 \pm 0.14$ & $4.60 \pm 0.15$ & $4.21 \pm 0.05$ & $4.28 \pm 0.05$ \\
\hline Ammonia nitrogen $\left(\mathrm{g} \mathrm{L}^{-1}\right)$ & $2.61 \pm 0.03$ & $2.69 \pm 0.02$ & $2.83 \pm 0.01$ & $2.85 \pm 0.01$ & 2.94 & 2.98 \\
\hline Crude protein $\left(\mathrm{g} \mathrm{L}^{-1}\right)$ & 12.67 & 11.73 & 14.42 & 10.97 & 7.95 & 8.16 \\
\hline \multicolumn{7}{|l|}{ Volatile organic acids: } \\
\hline Acetic acid $\left(\mathrm{mg} \mathrm{L}^{-1}\right)$ & $<1$ & 126 & 407 & 207 & 215 & 551 \\
\hline Propionic acid (mg L ${ }^{-1}$ ) & $<1$ & $<1$ & $<1$ & 66 & $<1$ & $<1$ \\
\hline Butyric acid (mg L $\left.{ }^{-1}\right)$ & $<1$ & $<1$ & $<1$ & $<1$ & $<1$ & $<1$ \\
\hline \multicolumn{7}{|l|}{ Water-eluable elements } \\
\hline Calcium (mg L ${ }^{-1}$ ) & 43.4 & 56.5 & 54.3 & 86.0 & 36.3 & 61.8 \\
\hline Iron $\left(\mathrm{mg} \mathrm{L}^{-1}\right)$ & 5.33 & 5.56 & 5.20 & 4.88 & 4.26 & 6.91 \\
\hline Magnesium (mg L ${ }^{-1}$ ) & 4.57 & 5.81 & 6.30 & 12.5 & 11.4 & 9.63 \\
\hline Nickel $\left(\mathrm{mg} \mathrm{L}^{-1}\right)$ & $<4$ & $<4$ & 21.4 & 20.8 & $<4$ & $<4$ \\
\hline Phosphorus(mg L $\left.{ }^{-1}\right)$ & 132 & 145 & 161 & 139 & 151 & 151 \\
\hline Potassium (mg L ${ }^{-1}$ ) & 1,703 & 1,687 & 1,682 & 1,659 & 1,755 & 1,690 \\
\hline Sulfur (mg L $\left.\mathrm{L}^{-1}\right)$ & 46.6 & 43.2 & 56.9 & 43.1 & 47.3 & 49.6 \\
\hline
\end{tabular}

In case of multiple determinations, standard deviations are presented. 

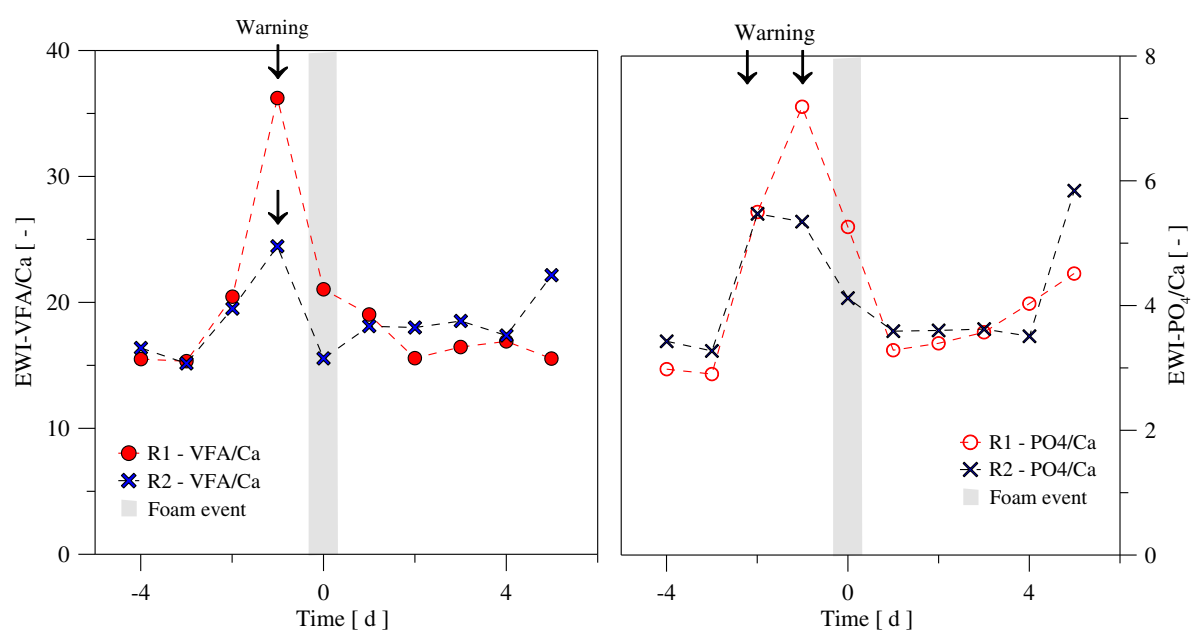

Figure 4 Early warning indicators EWI-VFA/Ca and EWI-PO 4 /Ca. Before, during, and after the foam event in the reactors R1 and R2 in month 1. Both indicators increase 1 to 2 days before foaming appeared. The increase is interpreted as a warning in terms of overloading. The overloading is regarded as reason for the formation of foam.

the chemical composition of the foam in order to confirm these assumptions.

\section{Stagnant zones, sedimentations, and process imbalances} due to stirring disturbances

The analysis of the rheology showed that the values for the Ostwald factor and the shear rate fluctuated considerably within the monitoring period of 6 months (Figure 5). Surprisingly, no significant changes of the rheological characteristics were detected during the period without stirring. Based on this rheological result, an Ostwald factor of $0.125 \mathrm{Pas}^{0,53}$ and a flow exponent of 0.53 were chosen for the CFD simulations. However, the power law approach was used for a shear rate range from 0.01 to $700 \mathrm{~s}^{-1}$ only. Outside this range, a constant viscosity of either 0.01 Pas or rather 4.03 was assumed. The open jet of the substrate supply was not considered in the simulation. The thoroughly mixed volume generated by the open jet was estimated as $5 \%$ to $10 \%$ of the whole reactor. With a feeding interval of $4 \mathrm{~h}$, the mixing process by substrate dosage was negligible. Under undisturbed mixing conditions, the numerical simulations showed a

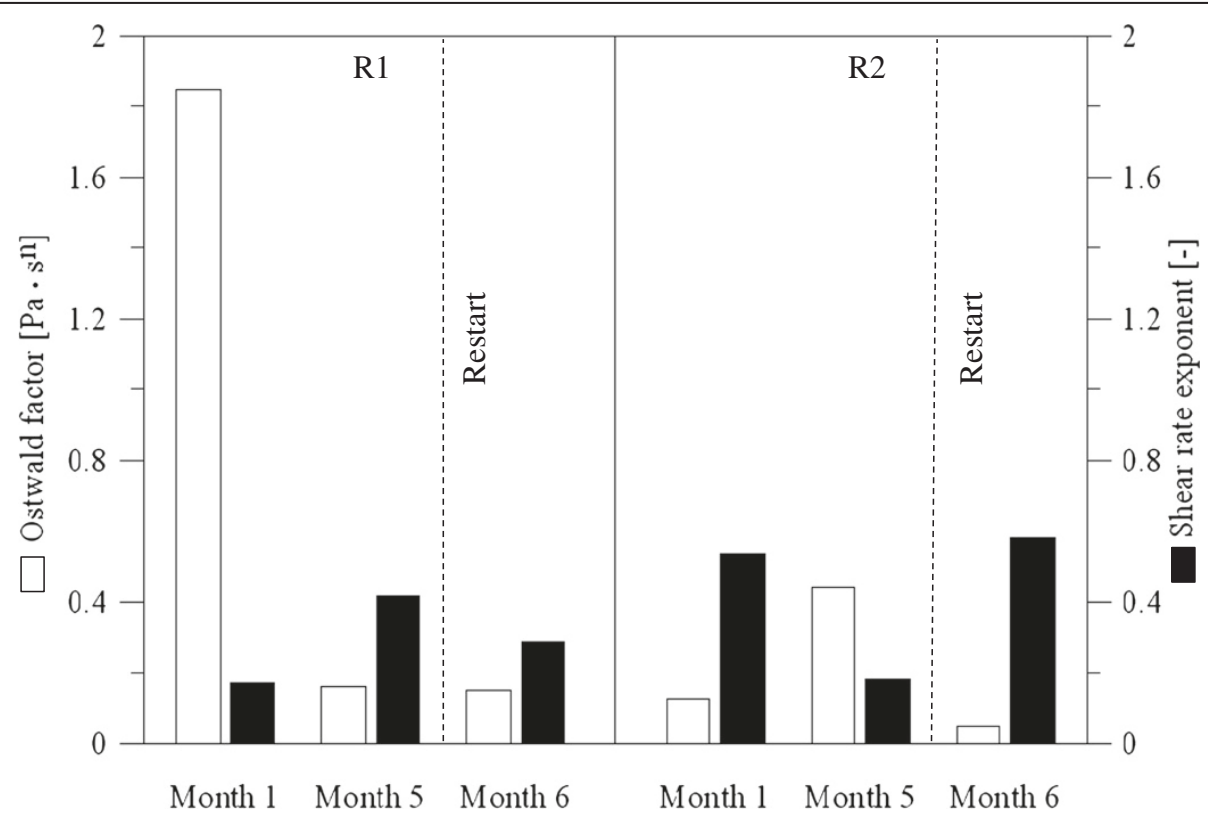

Figure 5 Ostwald factor and the shear rate exponent for R1 and R2. Ostwald factor and the shear rate exponent for R1 and R2 over 6 months covering the period of disturbed stirring. No considerable differences were detected during the stirring breakdown. 
good mixing for the studied biogas plant (Figure 6a). However, the partial stirring did not prevent the formation of floating layers in modeling the flow velocity since especially in the upper reactor volume, stagnant zones appeared (Figure 6b). The stagnation zone with a velocity less than $0.05 \mathrm{~m} \cdot \mathrm{s}^{-1}$ was limited to a volume of $52.6 \mathrm{~m}^{3}$ and represented $2.4 \%$ of the whole reactor. After breakdown of the lower agitator, large stagnation zones were formed, especially in the upper reactor volume with a volume of $487 \mathrm{~m}^{3}$ that was about $21.8 \%$ of the whole reactor and the whole flow field collapsed (Figure 6b). The concentrations of TS and VS in the monitoring period covering the time from agitator breakdown to the restart of stirring after 5 months differed slightly between R1 and R2 with differences from 3 to $4 \mathrm{~g} \mathrm{~L}^{-1}$ (Figure 7). The complete agitator downtime in R1 most likely led to sedimentations. The small volume of the introduced substrate was not sufficient to blend the reactor, and sedimentation occurred resulting in a $10 \%$ higher TS value and $13 \%$ higher VS value in R1 than in $R 2$ in which no or less

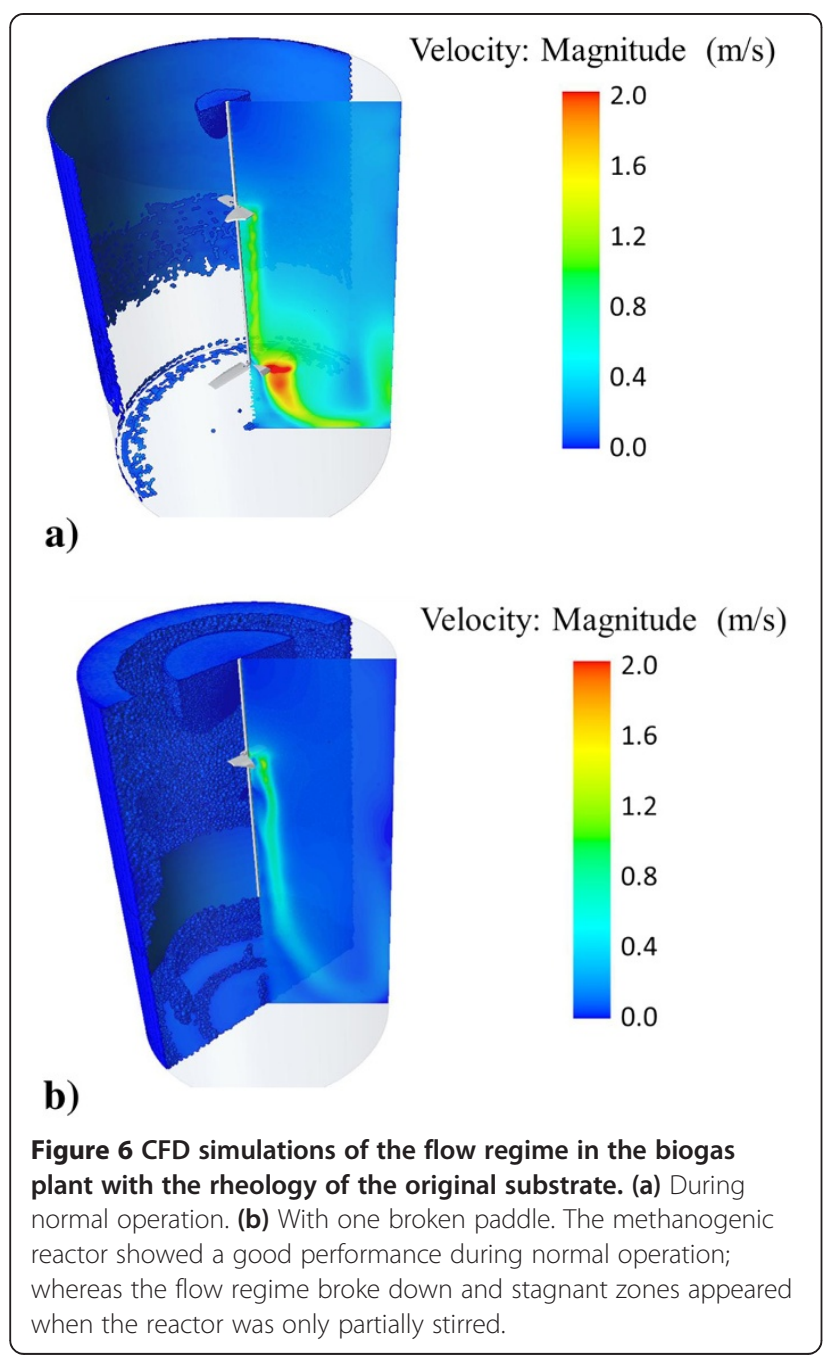

sedimentation occurred due to the partial mixing (Figure 7). The substrates were concentrated at the bottom of R1 and directly withdrawn at the drain during sampling which led to an overestimation of the average TS and VS values. In contrast to the complete stirring downtime in R1, the substrates in the partially stirred R2 were better distributed leading to a more sufficient degradation of organic matter and lower TS and VS values. The average $\mathrm{pH}$ values of the digestates of the methanogenic reactors were slight alkaline with a value of about 8 (Figure 7 ). The gas production rate was decreased by $16 \%$ to $36 \%$ during the mixing disturbances (Figure 8). Unfortunately, the biogas production of the two reactors was quantified together so that the comparison of the biogas production rate was not feasible. Analysis of the VFA concentrations in the methanogenic reactors showed increasing values after the agitators were broken (Figure 8). In the first 2 months, the VFA in both reactors nearly doubled from about $2,500 \mathrm{mg} \mathrm{L}^{-1}$ to $3,900 \mathrm{mg} \mathrm{L}^{-1}$ and the EWI-VFA/Ca increased two to three times. According to Kleyböcker et al. [3] the twoto threefold increase in the EWI-VFA/Ca indicates a process imbalance. However, the VFA concentrations in the hydrolytic reactors increased as well. In the first month, the VFA concentrations in both hydrolytic reactors reached a value of about $18,500 \mathrm{mg} \mathrm{L}^{-1}$ and increased in the second month up to more than $23,000 \mathrm{mg} \mathrm{L}^{-1}$. Afterward, the concentrations decreased constantly to less than $14,000 \mathrm{mg} \mathrm{L}^{-1}$ in month 5. Correspondingly, from month 3 onward, the VFA concentrations in the two methanogenic reactors decreased and stabilized at a value of around 1,200 $\mathrm{mg} \mathrm{L}^{-1}$, and the EWI-VFA/Ca also indicated process stabilization. The small intensity of stirring very likely favored the stabilization process. Stroot et al. [30], Gomez et al. [31], and Kaparaju et al. [32] also observed process stabilization due to gentle and/or minimal mixing (intermittent mixing) after high organic loading. It is probable that the increased concentrations of VFA in the methanogenic reactors were mainly caused by higher VFA concentrations in the fed substrate combined with an insufficient distribution of the substrate due to the stirring disturbances. Rojas et al. [33] revealed a decreasing performance of the biogas process in a reactor without stirring and related it to the insufficient contact between substrate and microorganisms. After restart of the agitator in month 5, the VFA concentrations in the two methanogenic reactors remained on a low level although the VFA concentrations in the hydrolytic stage increased again to more than $24,000 \mathrm{mg} \mathrm{L}^{-1}$. In month 5 , a floating layer sample was collected from the surface of R2 during the exchange of the broken stirring paddle. The TS and VS values of the floating layer were increased four- to fivefold related to the digestate, and the VFA concentration was twofold higher than in the digestate at a value of 2,200 $\mathrm{mg} \mathrm{L}^{-1}$ (data not shown). The EWI-VFA/Ca 


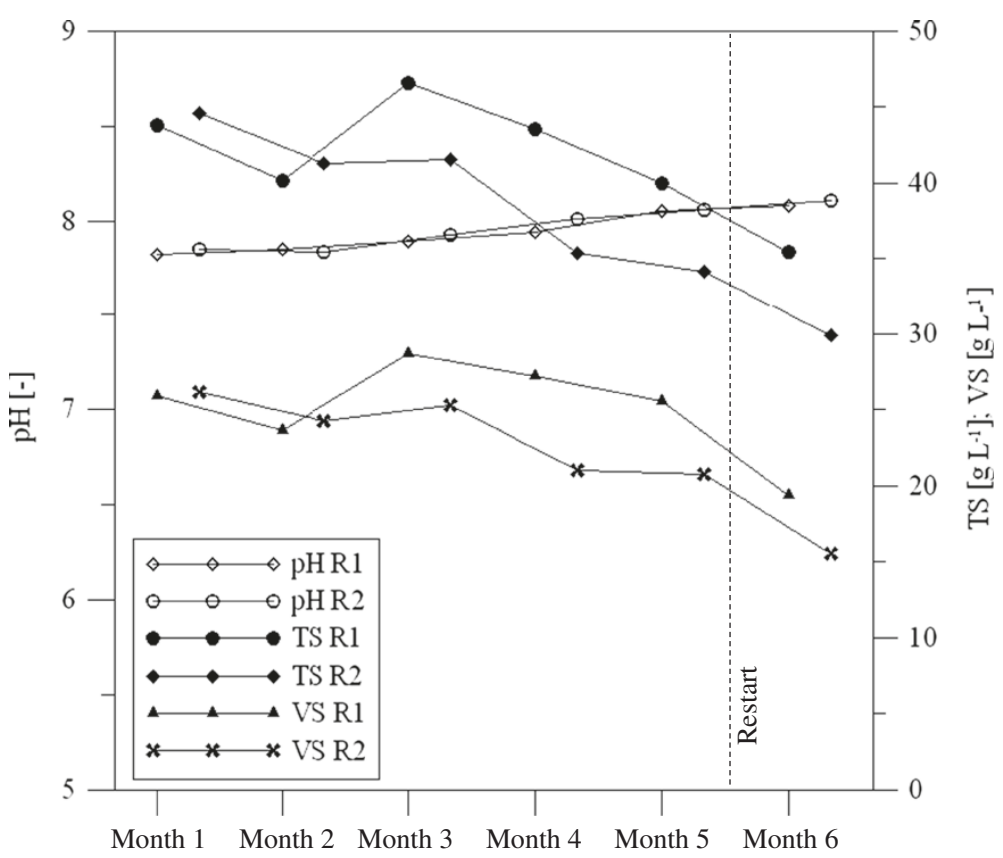

Figure 7 Average values of $\mathrm{pH}$, total solids, and volatile solids. Lower TS and VS values were detected in R2. The pH value increased and TS and VS values decreased slightly after restart of the agitator in month 5.

was increased fivefold compared to the digestate, whereas the EWI-PO 4 /Ca was increased threefold and indicated a process imbalance [3]. The accumulation of organic components in the layer and very limited exchange of intermediates within the layer led to an accumulation of VFA and therefore the microbial degradation process was inhibited in the floating layer.

\section{Process disruption-associated differences in the microbial} community

Genetic fingerprinting of the bacterial community composition in the two methanogenic reactors showed a diverse band pattern after agitator breakdown (Figure 9 a,b). One month after the stirring was disturbed in both reactors, the microbial composition changed and differed

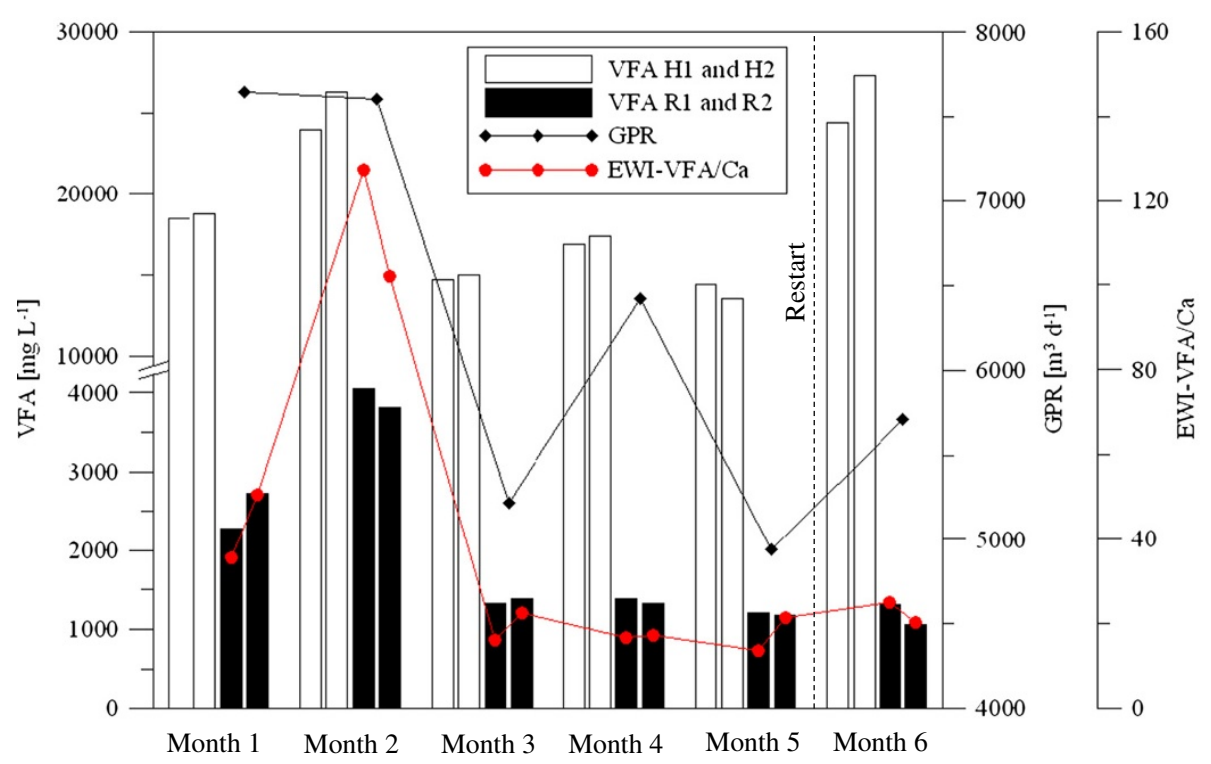

Figure 8 VFA concentrations, GPR, and early warning indicator (EWI-VFA/Ca). Highest VFA values in the hydrolytic reactors $\mathrm{H} 1$ and $\mathrm{H} 2$ in month 2 and month 6. VFA in the methanogenic reactors R1 and R2 increased and biogas production decreased after agitator disturbance. Afterward, the concentrations of VFA decreased and stabilized. 

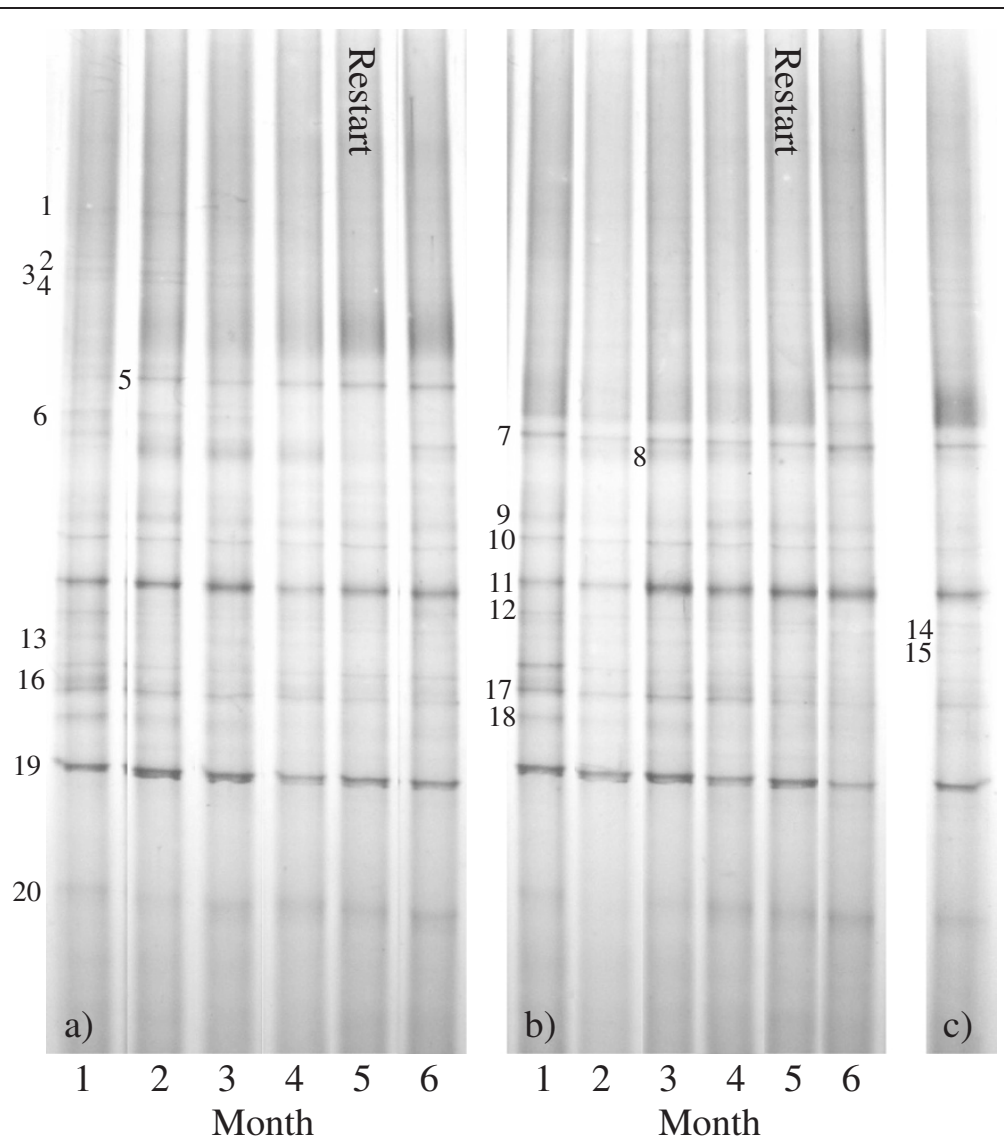

Figure 9 DGGE fingerprinting over 6-month monitoring. (a) R1 and (b) R2. Numbered bands were further identified by sequencing (Table 3). The bacterial community composition changed after the agitator disruption in month 1 and adjusted after restart of the agitator in month 5 . (c) DGGE pattern of floating layer showed no differences to the associated digestate of R2 in month 5.

between the two reactors. A characteristic band pattern for each reactor was visible at the genetic fingerprinting whereby mostly bacteria of the phyla Firmicutes and Bacteroidetes dominated the biocenosis (Table 3). Within the phylum Firmicutes, members of the order Clostridiales were dominant; whereas a Proteiniphilum-assigned organism from the phylum Bacteroidetes showed strong band intensities throughout the monitoring period, indicating a codominance in the reactors (band 19). In addition, one sequence was affiliated to a bacterium from the phylum Chloroflexi. Cardinali-Rezende et al. [34] as well as Leven et al. [35] investigated the microbial community of anaerobic reactors treating household waste and also observed bacteria of the Firmicutes, Bacteroidetes, and Chloroflexi as the dominating phyla. Although the band patterns of both reactors were similar in month 1 , differences in the intensities were detected for several bands. A higher abundance of an unclassified bacterium was indicated by the more intensive band 7 in R2 (Table 3). From month 2 on, the band patterns of R1 and R2 differed significantly. The intensity of band 5, which was affiliated to a bacterium from the order Bacteroidales, became stronger in R1 and weaker in R2. The unclassified bacterium (band 7) was less dominant in R1 from month four to month five; whereas its dominance increased in R2. After the restart of the agitator in month 5 , the band intensities from the Bacteroidales bacterium and the unclassified bacterium increased in both reactors again. The Pareto-Lorenz distribution pattern of R1 showed no differences in the functional organization of the microbial community during the agitator breakdown and afterward (Figure 10). Twenty percent of the cumulative number of bands was covered by $45 \%$ of the cumulative band intensities. By contrast, the Pareto-Lorenz distribution pattern of the partially stirred reactor R2 showed a difference in the functional organization of the microbial community in month 5 compared to months 1 and 6 as well as to the community in R1. In month 5 , only $20 \%$ of the bands covered nearly $80 \%$ of the band intensities, indicating an uneven microbial community composition with few dominant species. In month 6, after restart of the agitator, the evenness of the microbial composition improved to a value of about $45 \%$ and was again on the same level as observed for R1 indicating a similar microbial community composition. Both 
Table 3 Partial 16S rRNA gene sequences retrieved from DGGE fingerprint and sequencing excised bands

\begin{tabular}{|c|c|c|c|c|}
\hline Band ID & Genbank accession number & Closest relative (accession number) & BLAST similarity (\%) & Taxonomic classification \\
\hline 1 & KF147561 & Uncultured Clostridiales bacterium (JQ741982.1) & 91 & Unclassified Clostridiales \\
\hline 2 & KF147562 & Anaerobic bacterium (AY756145.2) & 91 & Unclassified Clostridiales \\
\hline 3 & KF147563 & Uncultured bacterium (GQ132906.1) & 83 & Unclassified bacteria \\
\hline 4 & KF147564 & Uncultured bacterium (JX224468.1) & 83 & Unclassified bacteria \\
\hline 5 & KF147565 & Uncultured bacterium (KC605949.1) & 82 & Unclassified Bacteroidales \\
\hline 6 & KF147566 & Uncultured Bacteroidetes bacterium (JX102011.1) & 99 & Unclassified Flavobacteriaceae \\
\hline 7 & KF147567 & Uncultured candidate division WWE1 (JX102010.1) & 94 & Unclassified bacteria \\
\hline 8 & KF147568 & Peptostreptococcaceae bacterium (AB377177.1) & 94 & Gallicola \\
\hline 9 & KF147569 & Clostridium sp. (FJ424481.1) & 98 & Clostridium sensustricto \\
\hline 10 & KF147570 & Uncultured bacterium (AB273806.1) & 87 & Unclassified Clostridiales \\
\hline 11 & KF147571 & Uncultured bacterium (AB850144.1) & 92 & Unclassified Clostridiales \\
\hline 12 & KF147572 & Uncultured compost bacterium (FN667344.1) & 90 & Unclassified Clostridiales \\
\hline 13 & KF147573 & Uncultured Firmicutes bacterium (FN429799.1) & 90 & Unclassified Clostridiales \\
\hline 14 & KF147574 & Uncultured bacterium (HQ156179.1) & 91 & Unclassified Clostridiales \\
\hline 15 & KF147575 & Uncultured bacterium (FN993992.1) & 89 & Unclassified Clostridiales \\
\hline 16 & KF147576 & Uncultured Syntrophomonas sp. (KF511597.1) & 95 & Syntrophomonas \\
\hline 17 & KF147577 & Uncultured Clostridia bacterium (JN998166.1) & 91 & Syntrophomonas \\
\hline 18 & KF147580 & Uncultured Firmicutes bacterium (HM041937.1) & 92 & Unclassified Clostridiales \\
\hline 19 & KF147578 & Uncultured bacterium (GQ134523.1) & 88 & Proteiniphilum \\
\hline 20 & KF147579 & Uncultured Chloroflexi bacterium (CU923171.1) & 99 & Levilinea \\
\hline
\end{tabular}

Taxonomic assignment was done by RDP Classifier with a confidence threshold of 50\%. Closest relatives are shown including Genbank accession numbers.

reactors were affected by foaming in the first month after agitator disruption and additionally a floating layer formation was found in R2 when the roof of the reactor was opened to repair the broken stirring paddle. Foaming and bulking caused by filamentous bacteria is well known in wastewater treatment plants (WWTP) and anaerobic digesters treating activated sludge [7]. A Proteiniphilum-like bacterium from the phylum Bacteroidetes dominated the microbial community in both reactors. Filamentous members of the Bacteroidetes phylum have been isolated from many environments [36-39]. However, little is known about the involvement of these microorganisms in bulking or foaming up until now [40], and the morphology of species from the genus Proteiniphilum was described as rod-shaped [41]. Additionally, a member from the phylum Chloroflexi was identified in the reactors. Some members
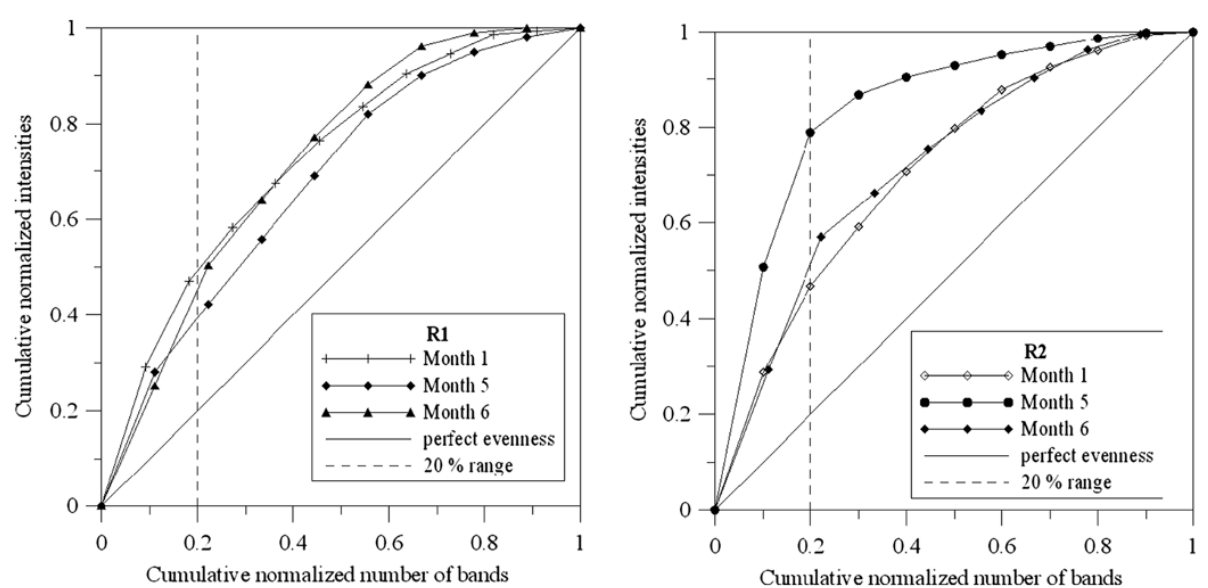

Figure 10 Pareto-Lorenz distribution pattern of R1 and R2 in months 1, 5, and 6. Perfect evenness is illustrated by straight line and $20 \%$ range is illustrated by dashed vertical line. Broken stirring paddle in $\mathrm{R} 2$ had greater influence on microbial evenness than complete downtime of agitator in R1. 


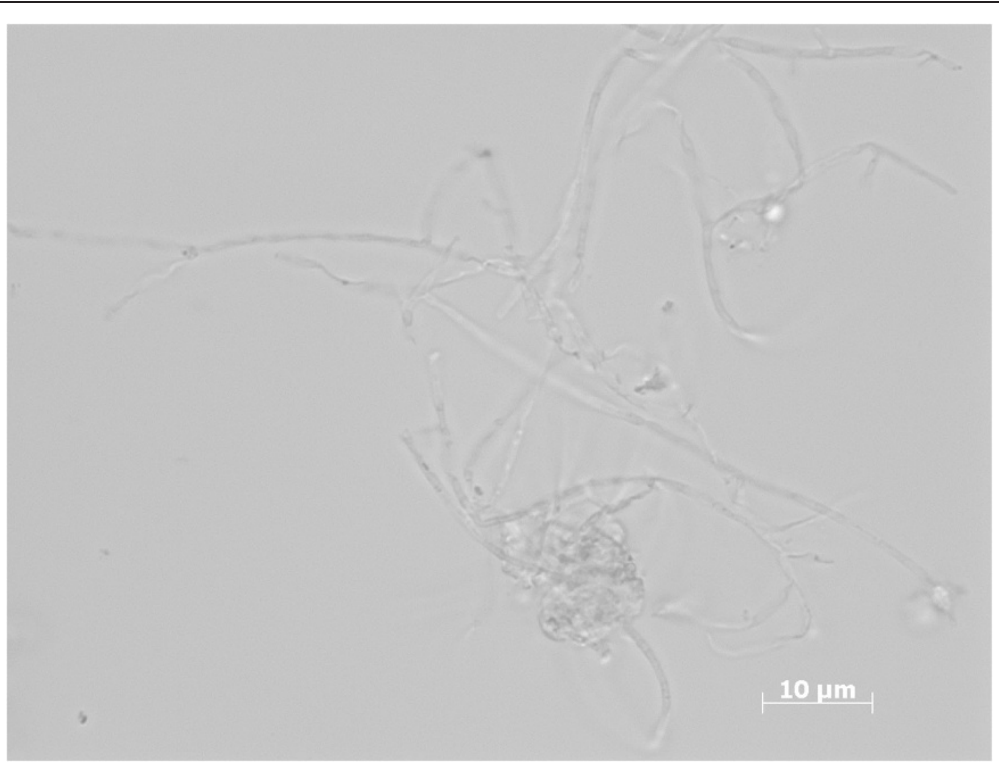

Figure 11 Filamentous structures in the floating layer sample ( $\times 100$ magnification).

of this phylum have a filamentous morphology occasionally triggering the formation of foam and floating layers in WWTP [42,43]. Accordingly, microscopic analyses (Figure 11) revealed filaments in the floating layer. It is arguable if the filamentous morphology of the microorganisms was an adaption to the deteriorated distribution of nutrients due to the disturbed mixing in both reactors because the filamentous structure allows an improved nutrient absorption or whether the microorganisms were obligatory filamentous. However, it is not clear if the filamentous bacteria promoted the floating layer formation in this case. Most likely, they were just accompanying bacteria and the floating layer formation was mainly caused by fibrous substrates and especially the stirring failure. Furthermore, it has to be discussed if the alternating substrate mix might have had an influence on the microbial community composition in the reactors. Since the exact amount of introduced substrates for every month is not known by the authors, a correlation between substrate loading and microbial community change was not possible. However, both methanogenic reactors were fed by the same substrate mix with similar VFA as well as TS and VS concentrations. Moreover, the microbial community structure only changed after the stirring differed in the reactors and adapted again after the stirring was restarted. Therefore, it is reasonable to regard the disturbance of stirring as the main trigger of the microbial community composition change. The band pattern of the floating layer showed no differences to the associated digestate (Figure 9c). Apparently, the microorganisms in the floating layer were not able to degrade efficiently the accumulated organic acids, although Syntrophomonas-like organisms which are known to withstand high VFA concentrations were detected in the floating layer [44]. Probably, the VFA concentrations were too high for a sufficient degradation leading to an inhibition of the microorganisms. Moreover, the accumulated fibrous substrates in the floating layer were less degradable, as also described by Heiske et al. [45].

\section{Conclusions}

This study shows that the formation of floating layers and foam in full-scale biogas plants can be reduced by proper stirring. A precise knowledge of the rheology of the substrate mix and an appropriate agitation technology is essential for efficient mixing as well as optimized energy consumption. Furthermore, the stirring has a crucial influence on the microbial community structure. As most of the microorganisms are still uncultured and uncharacterized, further investigation on the microbial community composition is fundamental to enhance the efficiency of anaerobic digesters. Additionally, controlled substrate feeding as well as monitoring of EWI might prevent foaming due to overloading.

\section{Abbreviations \\ CFD: Computational fluid dynamics; DGGE: Denaturing gradient gel electrophoresis; DNA: Desoxyribonucleic acid; EWl: Early warning indicator; GPR: Gas production rate; PCR: Polymerase chain reaction; TS: Total solids; VFA: Volatile fatty acids; VOA/TIC: Volatile organic acids/total inorganic carbonate buffer; VS: Volatile solid.}

\section{Competing interests}

The authors declare that they have no competing interests.

\section{Authors' contributions}

TL carried out the molecular biological studies, sequence alignment, and drafted the manuscript. AK coordinated the sampling and carried out 
chemical analyses. MB conducted the rheological analyses and participated in the design of the study. LM and KG participated in the design of the study and performed detailed chemical analyses of the foaming event. MK and HW conceived of the study, participated in its design and coordination, and helped to interpret the results and to draft the manuscript. All authors read and approved the final manuscript.

\section{Acknowledgements}

The Authors wish to thank the German 'Federal Ministry for the Environment, Nature and Nuclear Safety' for funding the project 'Optgas' (FKZ 03 KB018) and the biogas plant operator for the cooperation. Special thanks go to Prof. Dr. Andreas Zehnsdorf and Dr. Roland Müller for helpful discussion and critical reading of the manuscript.

\section{Author details}

${ }^{1}$ GFZ German Research Centre, Telegrafenberg, 14473 Potsdam, Microbial GeoEngineering, Germany. ${ }^{2}$ TechnischeUniversität Berlin, Fachgebiet Verfahrenstechnik, Ackerstraße

71-76, Berlin 13355, Germany. ${ }^{3}$ Environmental and Biotechnology Centre, UFZ Helmholtz Centre for Environmental Research, Permoserstrasse 15, Leipzig 04318, Germany.

\section{Received: 14 February 2013 Accepted: 4 October 2013} Published: 24 October 2013

\section{References}

1. Balussou D, Kleyböcker A, McKenna R, Möst D, Fichtner W (2012) An economic analysis of three operational co-digestion biogas plants in Germany. Waste Biomass Valor 3(1):23-41

2. Kleyböcker A, Liebrich M, Kasina M, Kraume M, Wittmaier M, Würdemann H (2012) Comparison of different procedures to stabilize biogas formation after process failure in a thermophilic waste digestion system: influence of aggregate formation on process stability. Waste Manag 32(6):1122-30

3. Kleyböcker A, Liebrich M, Verstraete W, Kraume M, Würdemann H (2012) Early warning indicators for process failure due to organic overloading by rapeseed oil in one-stage continuously stirred tank reactor, sewage sludge and waste digesters. Bioresour Technol 123:534-41

4. Moeller L, Goersch K, Neuhaus J, Zehnsdorf A, Mueller RA (2012) Comparative review of foam formation in biogas plants and ruminant bloat. Energy Sustainability Soc 2:12

5. Bischofsberger W, Dichtl N, Rosenwinkel K, Seyfried C, Böhnke B (2005) Anaerobtechnik. Springer-Verlag, Berlin Heidelberg

6. Deublein D, Steinhauser A (2008) Biogas from waste and renewable resources. Wiley-VCH Verlag GmbH \& Co. Kga A, Weinheim

7. Martins A, Pagilla K, Heijnen J, van Loosdrencht M (2004) Filamentous bulking sludge-a critical review. Water Res 38(4):793-817

8. Westlund AB, Hagland E, Rothman M (1998) Foaming in anaerobic digesters caused by Microthrix parvicella. Water Sci Technol 37:51-55

9. Frigon D, Guthrie RM, Bachman GT, Royer J, Bailey B, Raskin L (2006) Long-term analysis of a full-scale activated sludge wastewater treatment system exhibiting seasonal biological foaming. Water Res 40(5):990-1008

10. Ganidi N, Tyrrel S, Cartmell E (2009) Anaerobic digestion foaming causes-a review. Bioresour Technol 100(23):5546-54

11. Barber W (2005) Anaerobic digester foaming: causes and solutions. Water 21 7 1:45-49

12. Pagilla KR, Craney KC, Kido WH (1997) Causes and effects of foaming in anaerobic sludge digesters. Water Sci Technol 36(6-7):463-470

13. DIN 38409-1 (1987) German standard methods for the examination of water, waste water and sludge; parameters characterizing effects and substances (group $\mathrm{H}$ ); determination of total dry residue, filtrate dry residue and residue on ignition $(H$ 1). Deutsches Institut Für Normung EV DIN. 38409-1:1987-01

14. Dumas JB (1831) Procedes de l'analyseorganique. Ann ChimPhys 247:198-213

15. Eder B, Schulz H (2007) Anlagentechnik. In: Eder B, Schulz H (ed) Biogas praxis, 4th edition. Ökobuch Verlag, pp 70-118

16. Burchard CH, Groche D, Zerres HP (2001) ATV Handbucheinfacher Messungen und Untersuchungen auf Klärwerken. Hirthammer Verlag München

17. Metzner AB, Otto RE (1957) Agitation of non-Newtonian fluids. AlChE J $3(1): 3-10$
18. Wilkinson WL (1960) Non-Newtonian fluids, fluid mechanics, mixing and heat transfers. Pergamon Press, London

19. Muyzer G, de Waal EC, Uitterlinden AG (1993) Profiling of complex microbial populations by denaturing gradient gel electrophoresis analysis of polymerase chain reaction-amplified genes coding for $16 \mathrm{~S}$ rRNA. Appl Environ Microbiol 59:695-700

20. Amann Rl, Stromley J, Devereux R, Key R, Stahl DA (1992) Molecular and microscopic identification of sulfate-reducing bacteria in multispecies biofilms. Appl Environ Microbiol 58:614-623

21. Hall TA (1999) BioEdit: A user-friendly biological sequence alignment editor and analysis program for Windows 95/98/NT. Nucleic Acids Symp Ser 41:95-98

22. Altschul SF, Gish W, Miller W, Myers EW, Lipman DJJ (1990) Basic local alignment search tool. Molec Biol 215:403-410

23. Wang Q, Garrity GM, Tiedje JM, Cole JR (2007) Naive Bayesian classifier for rapid assignment of rRNA sequences into the new bacterial taxonomy. Appl Environ Microbiol 73(16):5261-7

24. Lorenz MO (1905) Methods of measuring concentration of wealth. J Am Stat Assoc 9:209-219

25. Wittebolle L, Vervaeren H, Verstraete W, Boon N (2008) Quantifying community dynamics of nitrifiers in functionally stable reactors. Appl Environ Microbiol 74(1):286-293

26. Switzenbaum MS, Giraldo-Gomez E, Hickey RF (1990) Monitoring of the anaerobic methane fermentation process. Enzyme Microb Technol 12:22-730

27. Moeller L, Goersch K, Mueller RA, Zehnsdorf A (2012) Formation and suppression of foam in biogas plants - practical experiences. Agric Eng (Landtechnik) 67(2):110-113

28. Scholwin F, Liebetrau J, Edelmann W, Kaltschmitt M, Hartmann H, Hofbaue $H$ (2009) Biogaserzeugung und -nutzung. In: Energieaus Biomasse. SpringerVerlag, Berlin Heidelberg, pp 851-990

29. Miltimore JE, McArthur JM, Mason JL, Ashby DL (1970) Bloat investigations. The threshold fraction 1 (18S) protein concentration for bloat and relationships between bloat and lipid, tannin, $\mathrm{Ca}, \mathrm{Mg}, \mathrm{Ni}$ and $\mathrm{Zn}$ concentrations in alfalfa. Can J Anim Sci 50:61-68

30. Stroot P, McMahon K, Mackie R, Raskin L (2001) Anaerobic codigestion of municipal solid waste and biosolids under various mixing conditions - $I$. Digester performance. Water Res 35(7):1804-1816

31. Gomez X, Cuetos M, Cara J, Moran A, Garcia A (2006) Anaerobic codigestion of primary sludge and fruit and vegetable fraction of the municipal solid wastes: conditions for mixing and evaluation of the organic loading rate. Renew Energy 31:2017-2024

32. Kaparaju P, Buendia I, Ellegaard L, Andelidaki I (2008) Effects of mixing on methane production during thermophilic anaerobic digestion of manure: lab-scale and pilot-scale studies. Bioresour Technol 99(11):4919-4928

33. Rojas C, Fang S, Uhlenhut F, Borchert A, Stein I, Schlaak M (2010) Stirring and biomass starter influences the anaerobic digestion of different substrates for biogas production. Eng Life Sci 10(4):339-347

34. Cardinali-Rezende J, Debarry RD, Colturato LFDB, Carneiro EV, ChartoneSouza E, Nascimento AMA (2009) Molecular identification and dynamics of microbial communities in reactor treating organic household waste. Appl Microbiol Biotechnol 84:777-789

35. Levén L, Eriksson AR, Schnürer A (2007) Effect of process temperature on bacterial and archaeal communities in two methanogenic bioreactors treating organic household waste. FEMS Microbiol Ecol 59(3):683-93

36. Williams TM, Unz RF (1985) Isolation and characterization of filamentous bacteria present in bulking activated sludge. Appl Microbiol Biotechnol 22:273-282

37. Kaempfer P, Weltin D, Hoffmeister D, Dott W (1995) Growth requirements of filamentous bacteria isolated from bulking and scumming sludge. Water Res 29:1585-1588

38. Eilers H, Pernthaler J, Peplies J, Glockner FO, Gerdts G, Amann R (2001) Isolation of novel pelagic bacteria from the German bight and their seasonal contributions to surface picoplankton. Appl Environ Microbio 67:5134-5142

39. Lydell C, Dowell L, Sikaroodi M, Gillevet P, Emerson D (2004) A population survey of members of the phylum Bacteroidetes isolated from salt marsh sediments along the East Coast of the United States. Microb Ecol 48:263-273

40. Kragelund C, Levantesi C, Borger A, Thelen K, Eikelboom D, Tandoi V, Kong Y, Krooneman J, Larsen P, Thomsen TR, Nielsen PH (2008) Identity, 
abundance and ecophysiology of filamentous bacteria belonging to the Bacteroidetes present in activated sludge plants. Microbiol 154(3):886-94

41. Chen S, Dong X (2005) Proteiniphilum acetatigenes gen. nov., sp. nov., from a UASB reactor treating brewery wastewater. Int J Syst Evol Microbiol 55 (6):2257-61

42. Kragelund C, Levantesi C, Borger A, Thelen K, Eikelboom D, Tandoi V, Kong Y, van der Waarde J, Krooneman J, Rossetti S, Thomsen TR, Nielsen PH (2006) Identity, abundance and ecophysiology of filamentous Chloroflexi species present in activated sludge treatment plants. FEMS Microbiol Ecol 59(3):671-82

43. Nielsen PH, Kragelund C, Seviour RJ, Nielsen JL (2009) Identity and ecophysiology of filamentous bacteria in activated sludge. FEMS Microbiol Rev 33(6):969-98

44. Sousa DZ, Pereira MA, Smidt H, Stams AJM, Alves MM (2007) Molecular assessment of complex microbial communities degrading long chain fatty acids in methanogenic bioreactors. FEMS Microbiol Ecol 60(2):252-65

45. Heiske S, Schultz-Jensen N, Leipold F, Schmidt JE (2013) Improving anaerobic digestion of wheat straw by plasma-assisted pretreatment. J Atomic Mol Phys:Article ID 791353

doi:10.1186/2192-0567-3-20

Cite this article as: Lienen et al:: Floating layer formation, foaming, and microbial community structure change in full-scale biogas plant due to disruption of mixing and substrate overloading. Energy, Sustainability and Society 2013 3:20.

\section{Submit your manuscript to a SpringerOpen ${ }^{\circ}$ journal and benefit from:}

- Convenient online submission

- Rigorous peer review

- Immediate publication on acceptance

- Open access: articles freely available online

- High visibility within the field

- Retaining the copyright to your article 